\title{
THE IMPACT OF INFRASTRUCTURE SPENDING ON NEW BUSINESS FORMATION: THE IMPORTANCE OF STATE ECONOMIC DEVELOPMENT SPENDING
}

\author{
Ernest Preston Goss*
}

\begin{abstract}
Results from this study suggest that states, in order to encourage new business formation and to compensate for unfavorable economic conditions, have budgeted more funds to support economic development agency activities. It is concluded that past studies, by failing to control for state economic development agency spending in estimated regression equations, have underestimated the impact of infrastructure spending and taxes on the formation of new businesses. Findings indicate that only after controlling for economic development agency spending do infrastructure spending and taxes enter the estimated regression equation with statistically significant coefficients and with the expected signs.
\end{abstract}

\section{INTRODUCTION}

Research has demonstrated that improvements in roads, electricity service, railroads, telecommunication services, or in water and sewage systems support economic development. Yet the degree to which such public infrastructure expenditures stimulate economic development has been questioned and has formed the basis for considerable debate and disagreement among researchers and policymakers. The significance of the debate heightened as states and local governments across the United States trimmed relative spending on infrastructure from an average of 2.3 percent of GNP in 1964 to 1.7 percent in 1987 (Fox and Smith 1990).

As states reduced relative spending on infrastructure, they increased state economic development (ED) agency expenditures, intending to create new jobs and business establishments within their borders. According to surveys by the National Association of State Development Agencies (NASDA), states expanded their ED agency appropriations from an average of $\$ 5,101,000$ in 1982 to $\$ 32,547,467$ in 1990 (NASDA 1990). As a proportion of gross state product (GSP), this represents more than a four-fold increase in state ED spending in less than a decade.

Despite the growth in scope and size of state ED agency programs, little empirical work, other than case studies and descriptive statistics from surveys, has

\footnotetext{
*Jack MacAllister Chair in Regional Economics, Department of Economics and Finance, Creighton University, Omaha, Nebraska.
} 
been performed to test the effectiveness of these programs or to evaluate how the programs alter the calculated relationship between economic growth and infrastructure spending. If, for example, the relationship between spending on infrastructure and business formation differs among states according to the level of ED agency spending, then the estimation of business formation equations, without controlling for state ED spending, produces biased coefficients for the included infrastructure variable.

Displayed in Table 1 is a summary of infrastructure spending, ED agency spending, and business formation among the states for selected years. ED agency spending is divided into traditional recruitment activities (ED) and new startup measures (VCap). As presented in Table 1, states spent an average of more than $\$ 19$ million on ED in 1986. Recruitment expenditures ranged from just more than $\$ 1$ million for North Dakota to more than $\$ 187$ million for Illinois. State ED spending directed at new business ventures (VCap) ranged from no spending for 17 states to more than $\$ 96$ million for West Virginia. Per million dollars of GSP, states spent an average of $\$ 505$, with Colorado spending the least at $\$ 32$ and Washington spending the most at $\$ 4,910$.

\section{TABLE 1}

ED Spending, Infrastructure Spending, and Business Formation among States

\begin{tabular}{|c|c|c|c|c|}
\hline & Mnemonic & Mean & Minimum & Maximum \\
\hline $\begin{array}{l}\text { Economic development } \\
\text { spending }(1986)^{1}\end{array}$ & ED & $\$ 19,191,000$ & $\$ 1,087,000$ & $\$ 187,300,000$ \\
\hline $\begin{array}{l}\text { Venture capital and } \\
\text { startup assistance } \\
\text { (1986 estimate) }^{2}\end{array}$ & VCap & $\$ 9,961,700$ & $\$ 0$ & $\$ 96,700,000$ \\
\hline $\begin{array}{l}\text { Total ED spending } \\
\text { per } \$ 1,000,000 \text { in } \\
\text { gross state product } \\
\text { (GSP) }\end{array}$ & ED GSP & $\$ 505$ & $\$ 32$ & $\$ 4,910$ \\
\hline $\begin{array}{l}\text { Infrastructure spending } \\
\text { as \% of GSP } \\
(1982-86)\end{array}$ & Infr & $1.83 \%$ & $1.20 \%$ & $4.3 \%$ \\
\hline $\begin{array}{l}\text { Growth rate- } \\
\text { enterprises } \\
\text { (1986-88) }\end{array}$ & GrEntpr & $1.69 \%$ & $-3.72 \%$ & $15.56 \%$ \\
\hline $\begin{array}{l}\text { Growth rate- } \\
\text { establishments } \\
\text { (1986-88) }\end{array}$ & GrEstab & $6.53 \%$ & $-2.39 \%$ & $17.88 \%$ \\
\hline
\end{tabular}

${ }^{1}$ Data not available for Massachusetts.

${ }^{2}$ Data for 1986 is an average of spending over the five-year interval. 
State spending on infrastructure as a percent of gross state product in the period 1982-86 ranged from a low of 1.2 percent for six states to a high of 4.3 percent for Alaska. According to Small Business Administration (SBA) data, in the period 1986-88, growth rates in enterprises ranged from a low of -3.7 percent in Wyoming to a high of 15.6 percent in Delaware. During the same period, growth rates in establishments varied from a low of -2.39 percent in Wyoming to a high of 17.9 percent in Arizona. The SBA defines an enterprise as a distinct taxable business entity, while an establishment is defined as a distinct location. Thus, the SBA classifies a new branch location as an additional establishment but not as an additional enterprise.

Presented in Table 2 are univariate, or simple correlation coefficients, among the variables of interest. Data in Table 2 show state infrastructure spending posi-

TABLE 2

Simple Correlation Coefficients among ED Spending, Infrastructure Spending, and Business Formation

\begin{tabular}{lccc}
\hline \hline & $\underline{\text { ED GSP }}$ & $\underline{\text { Infr }}$ & GrEntpr \\
Infr & .158 & & \\
GrEntpr & -.154 & -.135 & \\
GrEstab & -.151 & -.103 & .971 \\
\hline
\end{tabular}

tively related to relative ED spending as a percent of gross state product (ED GSP) but negatively related to both measures of new business formation. Moreover, there exists a paradoxical negative relationship between ED GSP and business formation. Rather than indicating that ED spending and infrastructure spending negatively influence business formation, the negative correlations likely signify that states, with past low levels of business formation, spend greater amounts on ED and infrastructure in order to encourage future development. Given the potential interaction among infrastructure spending, economic development spending, and business formation, it is important that research identify how the interaction affects empirical results obtained from regression analysis.

It is the hypothesis of this study that in order to more properly gauge the impact of infrastructure spending on business formation, the researcher must control for state ED spending. While the objective of this study is not to rigorously specify the regression equation explaining new business formation or openings, the intent is to indicate the direction and specification of future regression models, examining the impact of state economic factors on business openings. Specifically, the subsequent analysis, after controlling for other important factors found to affect business formation, will determine: 
1. If ED spending has a statistically significant impact on business openings.

2. If the inclusion of ED spending in the estimated regression equation alters the calculated relationship between infrastructure spending and business formation.

Presented in the next section is an overview of past empirical work, examining the impact of infrastructure spending on economic growth.

\section{INFRASTRUCTURE SPENDING AND ECONOMIC GROWTH}

Past researchers have generally measured a strong positive link between economic growth and spending on infrastructure. Many scholars, in fact, consider a deteriorating infrastructure as the primary impediment to successful business recruitment (Salvatore 1976; Biehl 1980). Verifying this nexus, DeRooy (1978) found investments in social overhead capital, when complemented with private capital, to be a highly significant factor explaining regional economic development. Similarly, Aschauer (1989) calculated that non-military public capital had a dramatic and positive impact on employment growth. He found core infrastructure of streets, highways, airports, mass transit, sewers, and water systems provided the most explanatory power in models estimating state employment gains.

Likewise, Munnell (1990), using regression analysis, concluded that states, which have invested more heavily in infrastructure, tend to have greater output and employment growth. She calculated that while the statistical significance of infrastructure varied, the size of its estimated coefficient remained virtually unchanged regardless of modifications made in the estimation specification. Munnell's calculations indicated that a $\$ 1,000$ increase in public infrastructure per capita contributed approximately .2 percent to the average annual rate of employment growth. Further, Munnell concluded that none of the components of public capital exhibited increasing or decreasing returns to scale as proposed by Hansen's (1962) earlier research.

On the other hand, some researchers have not been as "bullish" on the positive linkage between economic growth and infrastructure spending. Though Eberts (1986) estimated that public capital stock made a positive and statistically significant contribution to manufacturing output, he calculated its output elasticity as only .03 . Further questioning a strong positive relationship between employment growth and infrastructure spending, Hansen (1962) proposed that, in terms of stimulating manufacturing economic growth, public capital spending exhibited diminishing retums. However, Costa et al. (1987) found the negative elasticities, 
or diminishing returns as calculated by Hansen, were "spurious" since larger, less densely populated states are required to spend relatively more on infrastructure per capita.

Focusing on new business formation, research has shown that infrastructure spending is an important factor encouraging new firm development. In a study examining business openings in Tennessee counties, Fox and Murray (1991) calculated that highway expenditures encouraged firm openings. In a related study, Eberts (1991) found growth in the local public capital stock increased the birth rate of small firms in $\mathbf{4 0}$ metropolitan statistical areas. However, he concluded that this spending had no statistically significant impact on openings of large firms.

In summary, despite estimating a wide range of elasticities, past empirical research has, in general, calculated a positive relationship between infrastructure spending and economic growth or new business formation. None of the previous works, however, included any recognition of state ED agency spending. Using survey data collected by NASDA, the subsequent analysis shows how the inclusion of ED spending alters the estimated relationship between infrastructure spending and business formation. The next section presents an overview of state ED programs.

\section{STATE SPENDING TO SUPPORT BUSINESS FORMATION}

\section{Traditional Ed Spending}

Since the 1930s, states have invested heavily in business recruitment. From tax credits, direct financial subsidies, revenue bond financing, and construction loans to training outlays, states have spent generously on efforts to recruit businesses. During the depression of the 1930s, states vigorously enacted industrial recruitment policies, especially Southern states suffering from additional effects of the boll weevil invasion. For example, in the 1930s, Mississippi inaugurated the use of local industrial bond financing with its legislative program titled Balance Agriculture with Industry. This program, which signaled a more aggressive approach to business recruitment, allowed public borrowing of funds at relatively low rates of interest for private purposes.

During World War II, states reduced the use of formal economic development (ED) programs but expanded these programs over the decades following the war. In 1949, Maine, for example, authorized the first statewide business development corporation. By 1959, 31 states had duplicated Maine's efforts and created business development corporations. In 1955, New Hampshire created the first 
state industrial finance authority, which guaranteed direct loans made by private financing corporations.

Another major expansion of state business recruitment programs came during the latter half of the 1970 s and the early 1980 s as states attempted to reduce the impacts of high unemployment and rampant inflation. The battle to offer the most comprehensive benefits became so intense that Business Week (1976) editors termed it the second "War Between the States."

\section{Business Startup Assistance}

Although the majority of economic development expenditures continues to be devoted to recruitment, the focus of economic development has shifted somewhat over the past decade to the incubation of indigenous firms within the states (Smith and Fox 1990). From 1980 to 1986, 23 states adopted formal startup assistance programs, totaling 33 states offering this type of assistance. In 1986, 11 states provided $\$ 39.8$ million in state-funded venture capital funds (matched with private funds); 27 states contributed $\$ 274.5$ million for incubation loans; and 30 states provided $\$ 214.2$ million for research and development grants (Livingston 1989).

These programs vary in size from a current portfolio of 266 firms in Pennsylvania to only two companies in Wisconsin. Programs vary in scope from Kentucky's and Mississippi's direct loan program for industrial buildings and equipment to Connecticut's High-Tech Council, which spearheaded legislation creating a $\$ 17$ million high-tech development program (Bailey 1983). Other programs designed to encourage indigenous high-tech development offer such incentives as training and educational programs, capital assistance, and tax abatement (Patterson 1986). North Carolina, for instance, offers one-time $\$ 50,000$ research grants in exchange for a negotiated percent of net sales (Rozen 1985).

Although many states allocate seemingly insignificant funds to startup and recruitment activities, the fact programs and expenditures are the result of legislative mandates and oversight argues for their significance and inclusion in regression equations explaining new business formation. As such, it is the hypothesis of this study that researchers, in the analysis of business openings, should control for such spending in the estimated equation. The next section develops the methodology that will be used to examine the relationship among infrastructure spending, ED spending, and business formation. 


\section{EMPIRICAL RESULTS}

The following specification represents the structural specification of the equations that will be estimated empirically:

$$
\begin{aligned}
& \text { GrEntpr }=\beta_{0}+\beta_{1} E D \text { GSP }+\beta_{2} \text { Infr }+\beta_{3} Z+\mu \\
& G r E s t a b=\beta_{0}+\beta_{1} E D G S P+\beta_{2} \text { Infr }+\beta_{3} Z+\mu
\end{aligned}
$$

where GrEntpr and GrEstab are variables representing business startup rates, Infr is a variable representing relative public infrastructure spending, ED GSP is a variable representing state ED spending as a percent of GSP, and $\mathrm{Z}$ is a vector of exogenous variables. As suggested by data in Table 2 and confirmed by DuffyDeno and Eberts (1988), infrastructure spending is an endogenously determined variable. In addition to concluding that infrastructure spending was endogenously determined, the researchers, using data from 28 SMSAs, concluded that this spending is an important input into the regional production process and that the use of single-stage estimation produces biased results.

Moreover, ED spending is controlled for and is likewise assumed to be an endogenous variable in the estimations of Equations (1) and (2). Lyne (1988) found that states with the lowest or poorest performance were the ones that expended the most funds for firm development. In his 1988 survey, he found that those states with more extensive ED programs experienced less success in terms of new business formation (e.g., Pennsylvania and Rhode Island) than those states with fewer ED spending programs (e.g., Arizona and California). If states with otherwise unfavorable economic conditions are the same ones that aggressively spend on ED, as proposed by Lyne, then single-stage regression models would measure a negative correlation between ED spending and new business formation, despite the effectiveness of ED spending in generating business formation. Thus, to properly determine the relationship between ED spending and new business formation, the researcher should assume that ED spending is endogenous.

Definitions of all variables included in Equations (1) and (2), along with the sources of data, are listed in Table 3. Candidate independent variables to be included in the model are arguably limitless but were restricted to those traditionally used in past empirical studies. Altemative model specifications were empirically estimated. However, the selection of alternative models had little or no impact on the tests of hypotheses. Presented in the next section is a short discussion of the control, or exogenous, variables included in $\mathrm{Z}$. 
TABLE 3

List of Variables and Sources of Data

\begin{tabular}{|c|c|c|}
\hline Variable & Description & Dats Source \\
\hline GrEntpr & $\begin{array}{l}\text { State growth rate in enterprises } 1986-88 \text {. } \\
\text { Enterprise is defined as a business entity } \\
\text { (excludes new branches). }\end{array}$ & $\begin{array}{l}\text { The State of Small Business, } \\
\text { SBA, U.S. Govermment } \\
\text { Printing Office, } 1989 \text { and } 1991 .\end{array}$ \\
\hline GrEstab & $\begin{array}{l}\text { State growth rate in establishments } 1986-88 \text {. } \\
\text { Establishment is defined as a business location } \\
\text { (includes new branches). }\end{array}$ & $\begin{array}{l}\text { The State of Small Business, } \\
\text { SBA, U.S. Govemment Printing } \\
\text { Office, } 1989 \text { and } 1991 \text {. }\end{array}$ \\
\hline ED GSP & $\begin{array}{l}\text { Total state ED agency outlays in } 1986 \text { per million } \\
\text { dollars of gross state product. Spending includes } \\
1986 \text { operating budget for ED agencies plus agency } \\
\text { spending to support business startups (venture capital } \\
\text { outlays + direct loans + research grants). }\end{array}$ & $\begin{array}{l}\text { Operating budgets for ED agencies } \\
\text { from } 1986 \text { State Development } \\
\text { Agency Expenditure and Salary } \\
\text { Survey, National Association of } \\
\text { State Development Agencies, } \\
\text { 1986. Spending to support busi- } \\
\text { ness startups from Venture, } \\
\text { May } 1989, \text { p. } 63 \text {. }\end{array}$ \\
\hline Infr & $\begin{array}{l}\text { Infrastructure spending as a percent of gross state } \\
\text { product } 1982-86 \text {. Includes all categories of capital } \\
\text { expenditures by state and local governments, except } \\
\text { those for education, electric, and transit utilities. }\end{array}$ & $\begin{array}{l}\text { U.S. Dept of Commerce, Bureau } \\
\text { of the Census, Govermment } \\
\text { Finance as presented in Fox } \\
\text { and Smith (1990). }\end{array}$ \\
\hline PTax & $\begin{array}{l}\text { Average yearly total personal taxes per } \$ 1,000 \text { of } \\
\text { personal income: } 1982-86 \text {. }\end{array}$ & US. Statistical Abstract. \\
\hline CTax & Effective corporate tax rate: 1985. & U.S. Statistical Abstract. \\
\hline Sch Sp & $\begin{array}{l}\text { Average yearly per capita spending on primary, } \\
\text { secondary, and higher education: } 1982-86 \text {. }\end{array}$ & $\begin{array}{l}\text { U.S. Statistical Abstract and } \\
\text { Chronicle of Higher Education. }\end{array}$ \\
\hline$A v W_{k} W_{g}$ & Average weekly manufacturing salary: 1986. & US. Statistical Abstract. \\
\hline \%Man & Percent of work force employed in manufacturing. & U.S. Statistical Abstract. \\
\hline EngPr & Energy Prices; \$/million BTU & $\begin{array}{l}\text { State Energy Price and } \\
\text { Expenditure Report } 1983 .\end{array}$ \\
\hline IStock & $\begin{array}{l}\text { Logarithm of average state spending on infra- } \\
\text { structure } 1964-81 \text {. A proxy variable for the stock } \\
\text { of public capital. }\end{array}$ & $\begin{array}{l}\text { U.S. Dept of Commerce, } \\
\text { Bureau of the Census, } \\
\text { Govermment Finance as } \\
\text { presented in Fox and Smith } \\
(1990) \text {. }\end{array}$ \\
\hline JulyTmp & State's average temperature in the month of July. & US. Statistical Abstract. \\
\hline \%Metro & $\begin{array}{l}\text { Percent of state residing in metropolitan areas } \\
\text { in } 1986 .\end{array}$ & U.S. Statistical Abstract. \\
\hline South & $\begin{array}{l}\text { A binary variable equal to one if the state is in } \\
\text { the U.S. Census Bureau's South region; equal to } \\
\text { zero otherwise. }\end{array}$ & U.S. Statistical Abstract. \\
\hline West & $\begin{array}{l}\text { A binary variable equal to one if the state is in the } \\
\text { U.S. Census Bureau's West region; equal to zero } \\
\text { otherwise. }\end{array}$ & US. Statistical Abstract. \\
\hline
\end{tabular}

\section{Control Variables}

Traditional economic development factors must properly be controlled for in regression models examining business formation despite evidence from research studies that these traditional activities have had little impact on business location decisions (Schmenner 1982; Bartik 1985; Fox and Smith 1990).

Taxes. Though all states tax businesses to some extent, they do so at widely different rates. Furthermore, states that impose low tax burdens on businesses customarily assess relatively high tax burdens on households. Also relatively high 
household taxes impede the movement of productive labor to the state, ceteris paribus, making the state look less attractive for industrial expansion or relocation. Thus, in addition to corporate taxes, studies examining business formation should control for taxes applied directly to households. Most research studies, despite showing taxes to be relatively unimportant in location and business startup decisions, control for both personal and corporate taxes in regression analysis. In the present study, PTax and CTax are used to proxy the impact of taxes on business formation and are expected to possess negative signs in the estimated equations.

Education and Training. Evidence of state commitment to education has traditionally been one of the elements in the marketing portfolio of states attempting to entice firms to relocate to their area. Wasylenko and McGuire (1985) concluded that higher state and local spending on education favorably affects job growth. States attempt to attract firms by improving skills of workers directly or by demonstrating a commitment to improve or upgrade them. Senker (1985), Sklar (1985), and Engstrom (1987) found government-supported training programs to be particularly important for small innovative firms that depend heavily on an adequate supply of skilled workers. In the empirical estimations, spending on education is controlled for by inserting the variable Sch Sp and is expected to possess a positive sign in the estimated equations.

Other Factors. Paralleling the specifications of Duffy-Deno and Eberts (1988; 1991), variables were included to control for average weekly manufacturing wage ( $\mathrm{AvWkWg}$ ) for the percent of labor force employed in manufacturing (\%Man), for energy prices (EngPr), for the stock of public infrastructure (IStock), for warmer temperature (JulyTmp), and for proportion of population residing in metropolitan areas (\%Metro).

\section{Results}

Presented in Table 4 are the empirical estimations of Equations (1) and (2) using two-stage least squares with Infr and ED GSP assumed to be endogenously determined. ${ }^{1}$ Estimations of the first stage estimations of ED GSP and Infr are presented below but not discussed in detail. ${ }^{2}$ Presented in Columns (1) and (3) are the empirical estimations of business formation as proxied by GrEntpr and GrEstab respectively controlling for state ED spending (ED GSP). Presented in Columns (2) and (4) are the empirical estimations of GrEntpr and GrEstab without controlling for state ED spending.

Several important and statistically significant differences surface from the altemative specifications. First, as hypothesized, ED GSP has a positive impact on both the formation of new business enterprises and establishments. This result ap- 
TABLE 4

Impact of Infrastructure Outlays and Economic Development Spending on Business Formation

\begin{tabular}{|c|c|c|c|c|}
\hline \multirow[b]{2}{*}{ Variable } & \multicolumn{2}{|c|}{ Enterprise } & \multicolumn{2}{|c|}{ Establishments } \\
\hline & (1) & (2) & (3) & (4) \\
\hline$\beta_{0}$ & $\frac{-1.925}{(-3.394)}$ * & $\begin{array}{l}-0.4282 \\
(-2.427)\end{array}$ & $\begin{array}{l}-1.7023 * \\
(-2.951)\end{array}$ & $\begin{array}{c}-0.4940 \\
(-2.844)\end{array}$ \\
\hline ED GSP & $\begin{array}{l}0.5505^{*} \\
(2.755)\end{array}$ & & $\begin{array}{l}0.4443 * \\
(2.187)\end{array}$ & \\
\hline Infr & $\begin{array}{c}1.028 * \\
(2.710)\end{array}$ & $\begin{array}{r}.0599 \\
(1.086)\end{array}$ & $\begin{array}{l}0.8449 * \\
(2.190)\end{array}$ & $\begin{array}{r}0.0116 \\
(0.184)\end{array}$ \\
\hline PTax & $\begin{array}{l}-0.0024 * \\
(-2.240)\end{array}$ & $\begin{array}{r}.0003 \\
(0.607)\end{array}$ & $\begin{array}{l}-0.0021 * \\
(-1.975)\end{array}$ & $\begin{array}{l}0.0001 \\
(0.040)\end{array}$ \\
\hline CTax & $\begin{array}{l}-0.0162 * \\
(-2.776)\end{array}$ & $\begin{array}{r}-0.0013 \\
(-0.550)\end{array}$ & $\begin{array}{l}-0.0122 * \\
(-2.058)\end{array}$ & $\begin{array}{r}-0.0002 \\
(-0.084)\end{array}$ \\
\hline Sch Sp & $\begin{array}{r}0.0001 \\
(1.015)\end{array}$ & $\begin{array}{r}-0.0001 \\
(-0.709)\end{array}$ & $\begin{array}{l}0.0001 \\
(1.034)\end{array}$ & $\begin{array}{r}-0.0001 \\
(-0.310)\end{array}$ \\
\hline AvWkWg & $\begin{array}{l}-0.0023 * \\
(-2.573)\end{array}$ & $\begin{array}{l}0.0001 \\
(0.927)\end{array}$ & $\begin{array}{l}-0.0018 * \\
(-1.991)\end{array}$ & $\begin{array}{r}0.0001 \\
(1.082)\end{array}$ \\
\hline \%Man & $\begin{array}{l}4.7881 * \\
(2.804)\end{array}$ & $\begin{array}{l}0.1294 \\
(0.496)\end{array}$ & $\begin{array}{l}3.9947 * \\
(2.300)\end{array}$ & $\begin{array}{r}0.2350 \\
(0.915)\end{array}$ \\
\hline EngPr & $\begin{array}{l}0.0321 \text { * } \\
(4.159)\end{array}$ & $\begin{array}{l}0.0188 * \\
(2.881)\end{array}$ & $\begin{array}{l}0.0308 * \\
(3.926)\end{array}$ & $\begin{array}{l}0.0200 * \\
(3.129)\end{array}$ \\
\hline IStock & $\begin{array}{l}-0.9366^{*} \\
(-2.565)\end{array}$ & $\begin{array}{r}0.0599 \\
(1.086)\end{array}$ & $\begin{array}{l}-0.7372 * \\
(-1.985)\end{array}$ & $\begin{array}{r}0.0670 \\
(1.234)\end{array}$ \\
\hline JulyTmp & ${ }_{(2.077)}^{.0026 *}$ & $\begin{array}{l}0.0020 \\
(1.557)\end{array}$ & $\begin{array}{l}0.0026 * \\
(2.094)\end{array}$ & $\begin{array}{l}0.0022 \\
(1.706)\end{array}$ \\
\hline \%Metro & $\begin{array}{c}.0075 * \\
(2.950)\end{array}$ & $\begin{array}{r}.0005 \\
(1.592)\end{array}$ & $\begin{array}{l}0.0061 \text { * } \\
(2.389)\end{array}$ & $\begin{array}{l}0.0006 \\
(1.670)\end{array}$ \\
\hline $\mathbf{R}^{2}$ & .537 & .441 & .547 & .488 \\
\hline
\end{tabular}

*Indicates that the estimated coefficient is statistically different from zero at the 95 percent level of confidence.

pears consistent since a large portion of ED agency spending has traditionally been devoted to recruitment. For example, NASDA reported that in 1986, states spent a median 63 percent of their industrial development funds on recruitment efforts.

Second, after controlling for ED spending, Infr enters both estimated regression equations with the expected positive and statistically significant coefficient. In the traditional specification without controlling for ED spending (columns 2 
and 4), infrastructure spending is not a statistically significant variable explaining growth in enterprises or establishments. One cannot necessarily conclude from the empirical findings that ED spending has been a substitute for infrastructure spending. Alternatively, one may infer that this spending is a surrogate variable for a positive business environment or some other unmeasurable variable that alters the relationship between new business formation and its determinants such as infrastructure spending.

Contrary to expectations, the estimated coefficient for the variable IStock is negative. This indicates that states that have spent more heavily in the past on infrastructure are more likely to experience slower growth in new firms than states with lower spending. Given research has indicated that federal matching spending guidelines have strongly encouraged states to spend relatively more on new infrastructure and to spend relatively little on the maintenance of the stock (Peterson 1984), it is certainly plausible that crumbling infrastructure has more of a negative impact than the shortage of infrastructure. Moreover, the composition of infrastructure spending has changed dramatically since the 1960 s. According to Fox and Smith (1990), states devoted 57 percent of their infrastructure spending to highways in 1964 while they devoted only 39 percent of their infrastructure spending to highways in 1987 . Thus, the composition of infrastructure spending in the past could be an inappropriate measure of infrastructure needs of firms in the 1980s. Finally, past high spending on infrastructure could be a surrogate for higher taxes that are not captured by the variables PTax and CTax, but impede business development.

Controlling for ED spending produces a third and important difference in the empirical estimation with a calculation of negative and statistically significant coefficient for PTax and CTax. As estimated with the traditional specifications, PTax and CTax are statistically insignificant factors in explaining business formation. Many researchers have found taxes to be a relatively unimportant factor in explaining new business openings or business relocations (Schmenner 1982; Bartik 1985; Carlton 1985; Fox and Murray 1990). Each study has offered justifications for this apparent "aberration." None of these studies, however, controlled for state ED agency spending. Results from this study indicate that to more properly gauge the impact of taxes on business formation, the researcher should control for ED spending. It is plausible, and suggested by the results, that in order to overcome high taxes, states spend more heavily on economic development activities such as recruitment and new business development.

The preceding analysis does not argue that ED spending has necessarily been a substitute for economic factors or that ED agency spending singularly produced differential business formation, but instead may simply mean that the ED spending in the state is a proxy variable for a positive business climate or some other 
unobservable variable. This hypothesis can only be conjectured from the data in Table 4; however, it should serve to motivate future research on this matter.

Data presented in Tables 1,2, and 4 present a strong case for the inclusion of ED spending in the estimation of business formation equations. However, the preceding analysis, as with most empirical models explaining business formation, contains certain limitations. First, additional tests should be implemented that examine the lag structure between the independent variables and the dependent variable. Wasylenko and McGuire (1985) showed that such estimates are sensitive to the time frame used. However, this limitation is difficult to overcome since NASDA conducts their survey every four years, and the 1982 data was unavailable for nine states. Second, it could be argued that the estimation makes allowance for substate incentives. However, the ED spending data used in this study does account for local development spending that is channeled through state agencies (an average of $\$ 3,242,607$ in 1986). If these funds are good surrogates for local ED spending among the states, then this limitation is not a significant constraint.

\section{v. CONCLUSIONS}

Though the intent of the study was not to rigorously specify the regression equation modeling new business formation, the study did indicate several important considerations in the future construction of regression models examining this issue. ED spending is found to be effective in generating growth in new business ventures and locations. Moreover, results from this study show that after controlling for ED spending, the infrastructure spending variable increases in size and statistical significance as a factor influencing new business formation. This finding implies that by not controlling for state ED agency spending, past studies have underestimated the importance of infrastructure spending in generating business openings.

Finally, results imply that, in order to overcome the dampening impact of high taxes on business openings, states spend more heavily on economic development activities such as recruitment and new business development. After controlling for ED spending, the variables proxying personal and corporate taxes enter the regression equation with the expected negative and statistically significant sign. Findings from this study should serve as a step toward the specification of regression equations using cross-sectional and time series data that control for state business recruitment and startup activities. 


\section{ENDNOTES}

1. In order to econometrically identify Equations (1) and (2), regional dummies were added to the first stage estimations of ED GSP and Infr and were excluded from the estimation of Equations (1) and (2).

2.

\begin{tabular}{|c|c|c|c|c|c|c|c|c|c|c|}
\hline ED GSP & $\begin{array}{r}=1.3660 \\
(0.403)\end{array}$ & - & $\begin{array}{r}0.0063 \\
(-0.975)\end{array}$ & PTax & + & $\begin{array}{l}0.0573 \\
(1.256)\end{array}$ & CTax & + & $\begin{array}{l}0.0004 \\
(0.320)\end{array}$ & Sch Sp \\
\hline $\begin{array}{l}.0043 \\
(1.480\end{array}$ & AvWkWg & - & $\begin{array}{r}28997 \\
(-1.269)\end{array}$ & \%Man & + & $\begin{array}{l}0.0300 \\
(0.218)\end{array}$ & EngPr & + & $\begin{array}{l}0.5218 \\
(0.683)\end{array}$ & IStock \\
\hline $\begin{array}{l}0.0229 \\
(-0.96\end{array}$ & JulyTmp & - & $\begin{array}{r}0.0111 \\
(-1.637)\end{array}$ & \%Metro & + & $\begin{array}{l}0.3718 \\
(1.037)\end{array}$ & South & - & $\begin{array}{l}0.2120 \\
(-0.632)\end{array}$ & West \\
\hline
\end{tabular}

$\mathrm{R}^{2}=.27$

\begin{tabular}{|c|c|c|c|c|c|c|c|c|c|}
\hline Infr & $\begin{array}{l}0.7043 \\
(0.550)\end{array}$ & $\begin{array}{l}0.0059 \\
(2.430)\end{array}$ & PTax & & $\begin{array}{l}0.0145 \\
(-0.843)\end{array}$ & CTax & - & $\begin{array}{l}0.0003 \\
(-0.689)\end{array}$ & Sch Sp \\
\hline+ & $\begin{array}{l}.0002 \mathrm{AvW} / \mathrm{kWg} \\
(0.174)\end{array}$ & $\begin{array}{r}2.9844 \\
(-3.459)\end{array}$ & \%Man & & $\begin{array}{l}0.0239 \\
(-0.460)\end{array}$ & EngPr & + & $\begin{array}{l}0.6546 \\
(2.268)\end{array}$ & IStock \\
\hline & $\begin{array}{l}0.1121 \text { JulyTmp } \\
(1.247)\end{array}$ & $\begin{array}{r}0.0010 \\
(-0.393)\end{array}$ & \%Metro & & $\begin{array}{l}0.1609 \\
(-1.189)\end{array}$ & South & + & $\begin{array}{l}0.1483 \\
(1.170)\end{array}$ & West $R^{2}=.83$ \\
\hline
\end{tabular}

\section{REFERENCES}

Aschauer, David Alan. "Is Public Expenditure Productive?" Journal of Monetary Economics 23 (March 1980): 178-200.

Bailey, Douglas. "The Quest For High Tech." New England Business 5, no. 15 (September 1983): 68-75.

Bartik, Timothy. "Business Location Decisions in the U.S: Estimates of the Effects of Unionization, Taxes and Other Characteristics of States." Journal of Business and Economic Statistics 3, no. 1 (1985): 14-22.

Biehl, Dieter. "Determinants of Regional Disparities and the Role of Public Finance." Public Finance 35 (1980): 44-71.

Business Week. "War Between the States." (May 17, 1976).

Cariton, D. W. "Why New Firms Locate Where They Do: An Econometric Model." In Interregional Movements and Regional Growth, edited by W. Whaeton. COUPE Papers, vol. 2. Washington, D.C: Urban Institute, 1979. "The Location and Employment Choices of New Firms: An Econometric Model with Discrete and Continuous Endogenous Variables." The Review of Economics and Statistics 65, no. 3 (1983): 440-449.

Costa, Jose da Silva, Richard Ellson, and Randolph C. Martin. "Public Capital, Regional Output, and Development: Some Empirical Evidence." Journal of Regional Science 3 (1987). 
DeRooy, Jacob. "Productivity of Social Overhead Capital: North/South Comparisons." Review of Business and Economic Research 14 (1978): 45-59.

Duffy-Deno, K. T., and R. W. Eberts. "Public infrastructure and Regional Economic Development: A Simultaneous Equations Approach." Journal of Urban Economics 30 (1991): 329-343.

Eberts, R. W. "Estimating the Contribution of Urban Public Infrastructure to Regional Growth." Federal Reserve Bank of Cleveland, Working Paper no. $8610,1986$.

"Some Empirical Evidence on the Linkage Between Public Infrastructure and Local Economic Development." In Industry Location and Public Policy, edited by H. W. Herzog Jr. and A. M. Schlottmann. Knoxville: University of Tennessee Press, 1991.

Engstrom, Therese. "Little Silicon Valleys." High Technology 7 (January 1987): 24-32.

Fox, W. F., and M. N. Murray. "Local Public Policies and Interregional Business Development." Southern Economic Journal (forthcoming).

Fox, William, and Tim Smith. "Public Infrastructure Policy and Economic Development." Federal Reserve Bank of Kansas City, Economic Review (March/April 1990).

Hansen, Niles. "Unbalanced Growth and Regional Development." Western Economic Journal (Fall 1965).

Livingston, Abby. "State Capital." Venture (May 1989): 57-63.

Lyne, Jack. "States, Provinces Accelerate High-Tech Chase." Site Selection Handbook (June 1988): 630-631.

Munnell, Alicia. "How Does Public Infrastructure Affect Regional Economic Performance." New England Economic Review (September/October 1991): 1132.

National Association of State Development Agencies. State Development Agency Expenditure and Salary Survey. Washington, D.C., 1982, 1986 and 1990.

Patterson, William. "The 'New Silicon Valleys'." Industry Week 228, no. 2 (1986): 48-54.

Peterson, E. E. "Financing the Nation's Infrastructure Requirements" In Public Infrastructure Planning and Management, edited by R. Hanson. Beverly Hills, Calif.: Sage Publications, 1984.

Rozen, Miriam. "State Programs Lure High Tech Companies." Dun's Business Month 125, no. 3 (1985): 93.

Salvatore, Dominick. "Interregional Capital Flows and Development." Economia Internazionale 24 (1976): 66-78.

Schmenner, Roger. Making Business Location Decisions Englewood Cliffs, N.J.: Prentice-Hall, 1982. 
Senker, Jacqueline. "Small High Technology Firms: Some Regional Implications." Technovation (Netherlands) 3, no. 4 (1985): 243-262.

Sklar, R. A. "The American Electronics Industry: An Economic Development Perspective." Economic Development Review 3, no. 2 (1985): 61-69.

Smith, Tim, and William Fox. "Economic Development Programs for States in the 1990's." Economic Review (July/August 1990): 25-35.

Wasylenko, Michael, and Therese McGuire. "Jobs and Taxes: The Effect of Business Climate on States's Employment Growth Rates." National Tax Journal 38 (December 1985): 497-511. 